Prepared in cooperation with the Louisiana Department of Transportation and Development

\title{
Water Resources of Plaquemines Parish, Louisiana
}

\section{Introduction}

In 2010, about 85.1 million gallons per day (Mgal/d) of water were withdrawn in Plaquemines Parish, Louisiana $^{1}$ (fig. 1). Surface-water sources accounted for almost all withdrawals; groundwater sources accounted for only $0.04 \mathrm{Mgal} / \mathrm{d}$ (table 1). Industrial use accounted for about 92 percent of the total water withdrawn. Other

${ }^{1}$ Tabulation of numbers in text and tables may result in different totals because of rounding; nonrounded numbers are used for calculation of totals. categories of use included public supply, rural domestic, and livestock (table 2). Water-use data collected at 5-year intervals from 1960 to 2010 indicated that water withdrawals in Plaquemines Parish peaked at about $177 \mathrm{Mgal} / \mathrm{d}$ in 1975 (fig. 2). The peak resulted primarily from an increase in industrial surface-water withdrawals from about $23.8 \mathrm{Mgal} / \mathrm{d}$ in 1970 to $171 \mathrm{Mgal} / \mathrm{d}$ in 1975. Since 1975, water withdrawals have ranged from about 157 to $85.1 \mathrm{Mgal} / \mathrm{d}$, with industrial surface-water withdrawals accounting for most of the variation.

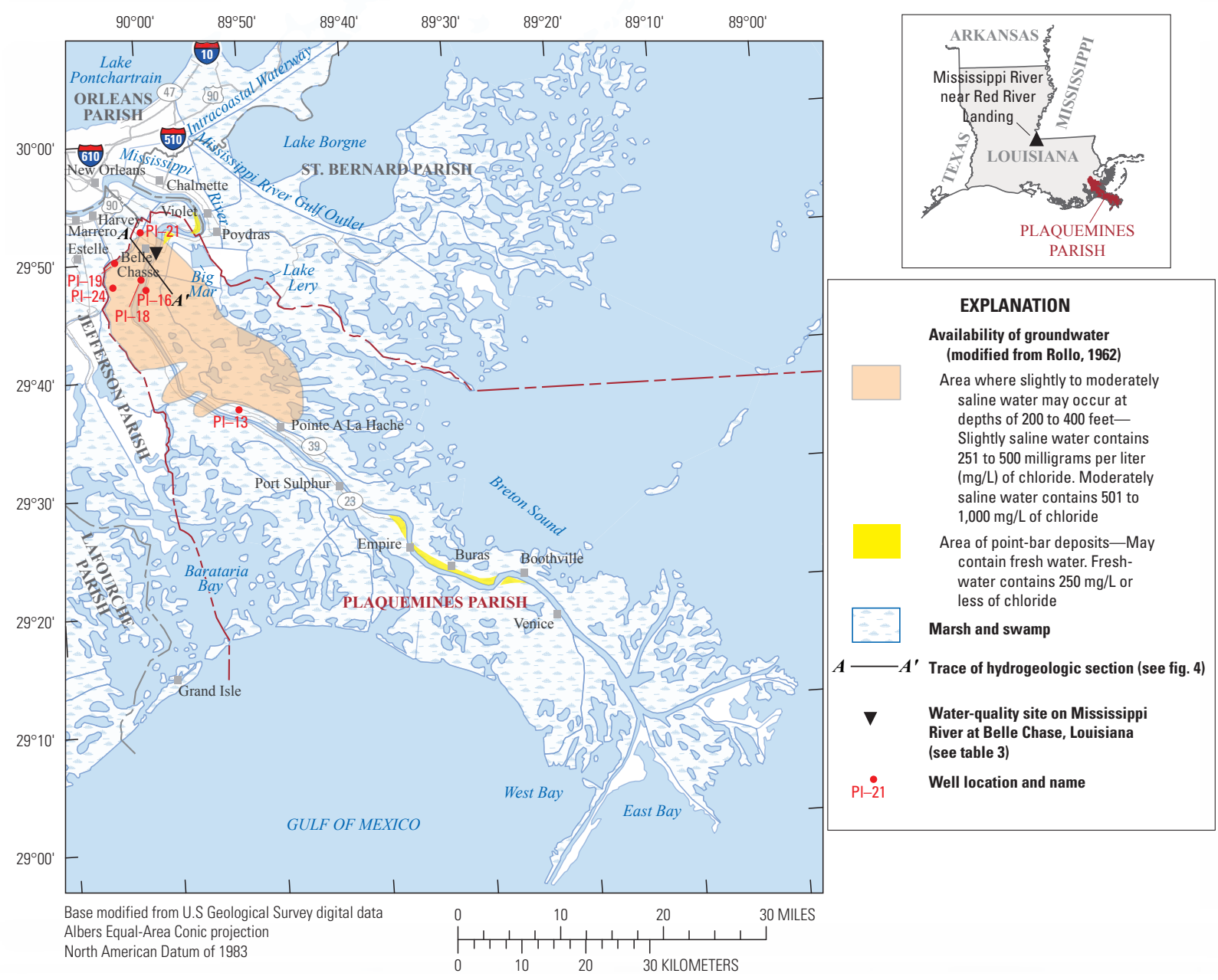

Figure 1. Location of the study area, Plaquemines Parish, Louisiana. 
Table 1. Water withdrawals, in million gallons per day, by source in Plaquemines Parish, Louisiana, 2010 (modified from Sargent, 2011).

\begin{tabular}{lcc}
\hline \multicolumn{1}{c}{$\begin{array}{c}\text { Aquifer or } \\
\text { surface-water body }\end{array}$} & Groundwater & Surface water \\
\hline Gramercy aquifer & 0.04 & 85.03 \\
Mississippi River & & 0.05 \\
$\begin{array}{l}\text { Miscellaneous streams } \\
\text { and ponds }\end{array}$ & 0.04 & 85.07 \\
\cline { 2 - 2 } & \\
\hline
\end{tabular}

Table 2. Water withdrawals, in million gallons per day, by category in Plaquemines Parish, Louisiana, 2010 (modified from Sargent, 2011).

\begin{tabular}{lccc}
\hline \multicolumn{1}{c}{ Category } & Groundwater & Surface water & Total \\
\hline Public supply & 0.00 & 6.32 & 6.32 \\
Industrial & 0.00 & 78.71 & 78.71 \\
Rural domestic & 0.04 & 0.00 & 0.04 \\
Livestock & 0.00 & 0.05 & 0.05 \\
Total & 0.04 & 85.07 & 85.11 \\
\hline
\end{tabular}

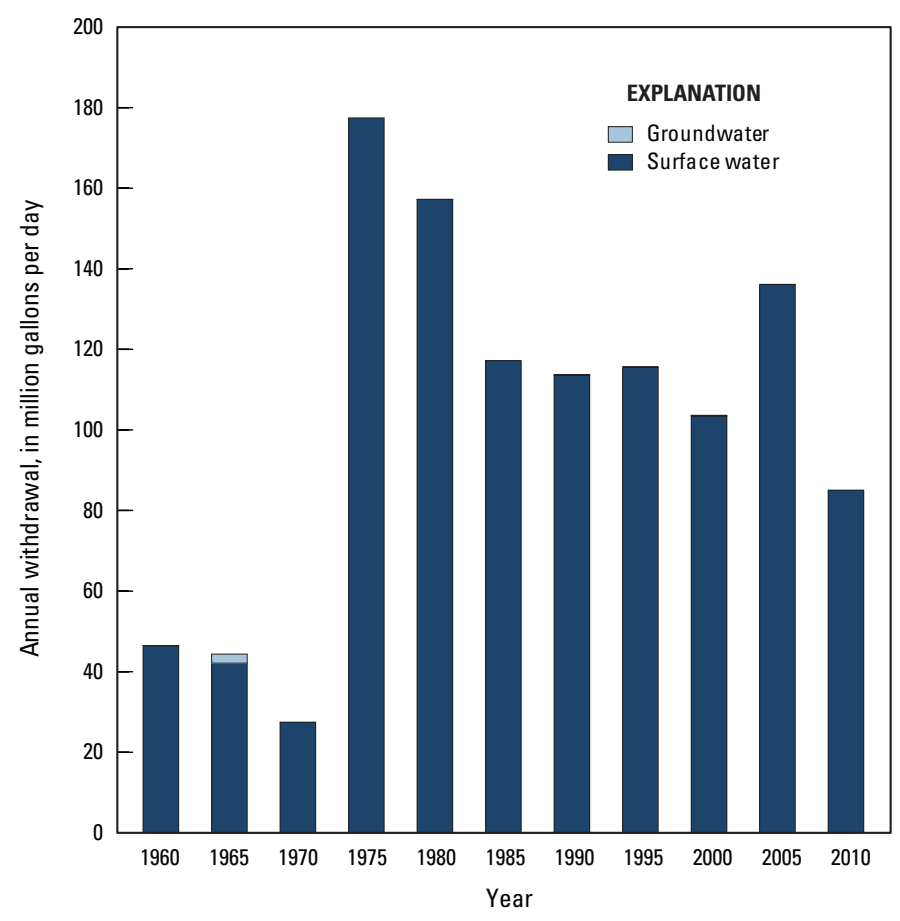

Figure 2. Water withdrawals in Plaquemines Parish, Louisiana, 1960-2010.
This fact sheet summarizes basic information on the water resources of Plaquemines Parish. Information on groundwater and surface-water availability, quality, development, use, and trends is based on previously published reports listed in the Selected References section.

\section{Groundwater Resources}

There are no major sources of fresh groundwater (water with a chloride concentration of 250 milligrams per liter $[\mathrm{mg} / \mathrm{L}]$ or less) in Plaquemines Parish. Limited sources of fresh groundwater could be available from shallow aquifers (point-bar and natural levee deposits) at depths generally less than 140 feet (ft) below the National Geodetic Vertical Datum of 1929 (NGVD 29), but these sources generally have not been developed or well documented. Saline water is available from the deeper Gramercy and Norco aquifers.

Recharge to aquifers in the parish is from rainfall, leakage from adjacent aquifers, and seasonally from the Mississippi River. Discharge from the aquifers is by natural flow into rivers or canals, leakage into adjacent aquifers, and withdrawals from wells. Mississippi River point-bar deposits will discharge water into the Mississippi River as the stage of the river falls.

\section{Shallow Aquifers}

Fresh groundwater resources in Plaquemines Parish are limited to natural levee deposits and possibly point-bar deposits located along the Mississippi River. Near-surface silt and very fine sand form lenses of permeable material within the generally clayey natural levee deposits of the Mississippi River (fig. 3). These lenses of permeable material yield the only known freshwater in the parish. Locally, these lenses may provide sufficient quantities of water for domestic wells not more than 20 to $30 \mathrm{ft}$ deep. State well-registration records for Plaquemines Parish in 2009 listed only one active well screened in these deposits; water well Pl-13 (fig. 1) is a domestic well drilled in 1957 at a depth of $30 \mathrm{ft}$ below land surface. Water from the well had a chloride concentration of $31 \mathrm{mg} / \mathrm{L}$ in 1962. Water levels in natural levee deposits fluctuate with the stage of the Mississippi River and are generally near land surface.

Point-bar sand deposits along the Mississippi River could be potential sources of fresh groundwater (fig. 1). These sands, hydraulically connected to the river, are subject to the infiltration of water from the river. The point-bar deposits are recharged with freshwater during periods of normal or high flow of the river; however, saltwater that intrudes up the river during periods of low flow may infiltrate and contaminate these sands. Although 


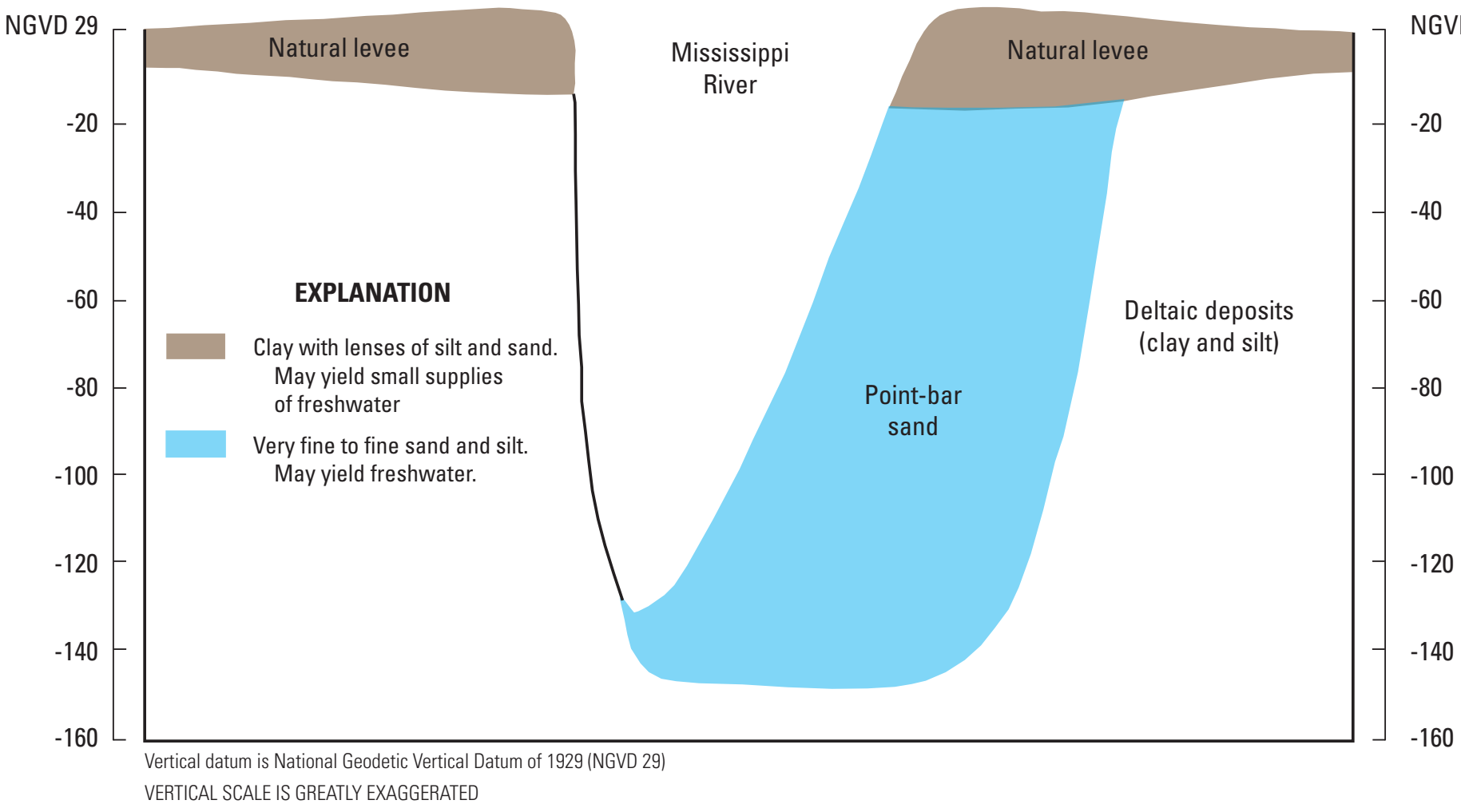

Figure 3. Generalized section through natural levee and point-bar deposits in Plaquemines Parish, Louisiana (modified from Rollo, 1962).

water-quality data have not been collected from pointbar deposits in Plaquemines Parish, wells drilled 50 to $100 \mathrm{ft}$ deep in point-bar deposits in the southeastern part of neighboring Orleans Parish have yielded small to moderate quantities of freshwater. Of note, however, is that water from these wells is generally of poor quality because of its high iron concentration and very high hardness ${ }^{2}$. State well-registration records for Plaquemines Parish in 2009 did not list any active wells screened in point-bar deposits.

\section{Deep Aquifers}

In northwestern Plaquemines Parish, slightly (251-500 $\mathrm{mg} / \mathrm{L}$ of chloride) to moderately (501-1,000 $\mathrm{mg} / \mathrm{L}$ of chloride) saline groundwater is available from the Gramercy aquifer. Large quantities of moderately to highly (greater than $1,000 \mathrm{mg} / \mathrm{L}$ of chloride) saline groundwater are available from the Gramercy aquifer throughout Plaquemines Parish. Three

${ }^{2}$ Hardness ranges, expressed as milligrams per liter of calcium carbonate, are as follows: 0-60, soft; 61-120, moderately hard; 121-180, hard; greater than 180 , very hard (Hem, 1985). wells $(\mathrm{Pl}-16,21,24)$ screened in the Gramercy aquifer in the northern part of the parish, ranging from 210 to $285 \mathrm{ft}$ deep and sampled between 1938 and 1961, yielded water with chloride concentrations of 250 to $500 \mathrm{mg} / \mathrm{L}$. Two other wells $(\mathrm{Pl}-18,19)$ screened in the Gramercy aquifer at depths of 300 and $248 \mathrm{ft}$ and sampled in the 1950s yielded water with chloride concentrations of 670 and $630 \mathrm{mg} / \mathrm{L}$. Electrical logs of oil-test wells in the northern part of the parish were used to outline the general area of occurrence of sands that contain slightly to moderately saline water between depths of about 200 to $400 \mathrm{ft}$ below land surface (fig. 1).

Figure 4 is a generalized geologic section illustrating the sands where slightly to moderately saline water exists. In some areas, highly saline water occurs in the lower part of the sand; therefore, water from largecapacity wells screened in the upper part of the sand could increase in salinity with continued pumping. State well-registration records listed 16 active water wells screened in the Gramercy aquifer in Plaquemines Parish in 2009, including 7 domestic, 7 irrigation, 1 industrial, and 1 public-supply well. Depths of these wells ranged 248-430 ft below land surface, with a median depth of $285 \mathrm{ft}$. Reported yields from wells screened in the Gramercy aquifer in Plaquemines Parish have ranged 


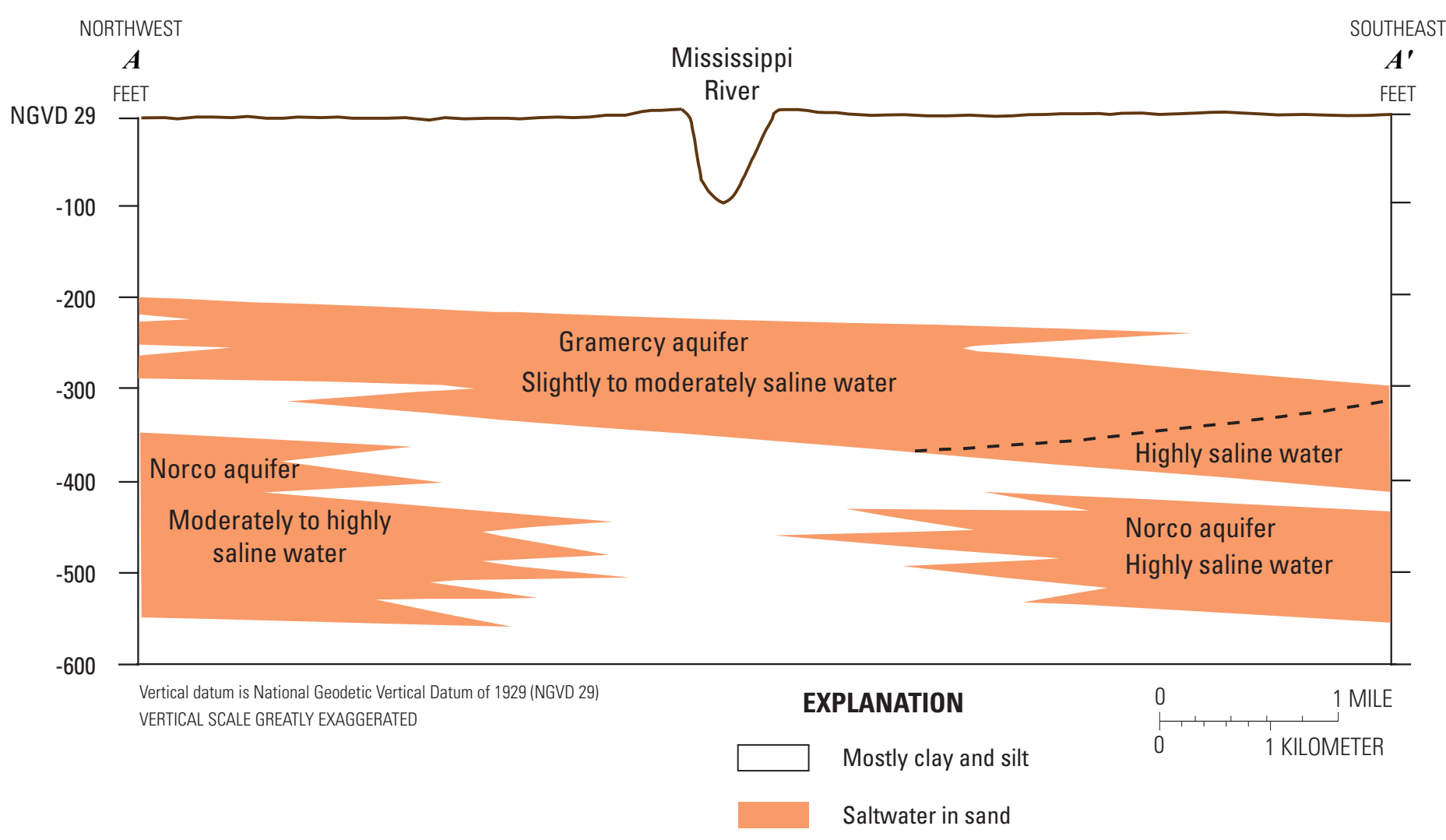

Figure 4. Generalized northwest-to-southeast geologic section in northern Plaquemines Parish, Louisiana (modified from Rollo, 1962). Trace of section shown on figure 1.

from 4 to 80 gallons per minute. In 2010, groundwater withdrawals from the Gramercy aquifer in Plaquemines Parish totaled about $0.04 \mathrm{Mgal} / \mathrm{d}$ (table 1), all for ruraldomestic use (table 2).

In northwestern Plaquemines Parish, moderately saline to highly saline water is available from the deeper Norco aquifer. The nearest freshwater within the Norco aquifer occurs near the Lake Pontchartrain shoreline in neighboring Jefferson Parish. In Plaquemines Parish, there were no registered active water wells screened in the Norco aquifer in 2009 and no known water withdrawals.

\section{Surface-Water Resources}

In 2010, about $85.1 \mathrm{Mgal} / \mathrm{d}$ of surface water were withdrawn in Plaquemines Parish, including 6.32 Mgal/d for public supply, $78.7 \mathrm{Mgal} / \mathrm{d}$ for industrial use, and $0.05 \mathrm{Mgal} / \mathrm{d}$ for livestock (table 2). The Mississippi River is the primary source of fresh surface water in Plaquemines Parish. In 2010, all public-supply and industrial-use water withdrawals in the parish came from the Mississippi River, whereas livestock withdrawals came from miscellaneous streams and ponds. Most surface water withdrawn by industry was used for oncethrough cooling and was returned to its source after use. The average flow of the Mississippi River near Red River Landing, about 226 river miles upstream of Belle Chasse (fig. 1, index map), was about 460,000 cubic feet per second for 1928-76.

Water samples analyzed during 1977-2009 indicated that water in the Mississippi River at Belle Chasse (fig. 1) is generally hard (table 3 ). Water in the river generally does not exceed the U.S. Environmental Protection Agency's Secondary Maximum Contaminant Levels ${ }^{3}$ (SMCLs) for drinking water for $\mathrm{pH}$ and concentrations of chloride, sulfate, and iron. Dissolved oxygen is generally greater than $5 \mathrm{mg} / \mathrm{L}$, which is considered the minimum value for a diversified population of fresh, warm-water biota, including sport fish.

\footnotetext{
${ }^{3}$ The SMCLs are nonenforceable Federal guidelines regarding cosmetic effects (such as tooth or skin discoloration) or aesthetic effects (such as taste, odor, or color) of drinking water. At high concentrations or values, health implications as well aesthetic degradation might exist. SMCLs were established as guidelines for the states by the U.S. Environmental Protection Agency (1992).
} 
Table 3. Summary of selected water-quality characteristics for the Mississippi River at Belle Chasse in Plaquemines Parish, Louisiana, 1977-2009.

[Values are in milligrams per liter, except as noted. $\mu \mathrm{S} / \mathrm{cm}$, microsiemens per centimeter; ${ }^{\circ} \mathrm{C}$, degrees Celsius; SU, standard units; $\mu \mathrm{g} / \mathrm{L}$, micrograms per liter; $\mathrm{CaCO}_{3}$, calcium carbonate; <, less than; NA, not applicable; SMCL, Secondary Maximum Contaminant Level established by the U.S. Environmental Protection Agency (2012)]

\begin{tabular}{|c|c|c|c|c|c|c|c|c|c|c|}
\hline & $\begin{array}{c}\text { Specific } \\
\text { conduc- } \\
\text { tance, field } \\
(\mu \mathrm{S} / \mathrm{cm} \\
\left.\text { at } 25^{\circ} \mathrm{C}\right)\end{array}$ & $\begin{array}{l}\text { Oxygen, } \\
\text { dis- } \\
\text { solved }\end{array}$ & $\begin{array}{l}\text { pH, } \\
\text { field } \\
\text { (SU) }\end{array}$ & $\begin{array}{l}\text { Hardness } \\
\text { (as } \mathrm{CaCO}_{3} \text { ) }\end{array}$ & $\begin{array}{c}\text { Calcium, } \\
\text { filtered } \\
\text { (as Ca) }\end{array}$ & $\begin{array}{c}\text { Magne- } \\
\text { sium, } \\
\text { filtered } \\
\text { (as } \mathrm{Mg} \text { ) }\end{array}$ & $\begin{array}{c}\text { Sodium, } \\
\text { filtered } \\
\text { (as Na) }\end{array}$ & $\begin{array}{l}\text { Chlo- } \\
\text { ride, } \\
\text { filtered } \\
\text { (as CI) }\end{array}$ & $\begin{array}{l}\text { Sulfate, } \\
\text { filtered } \\
\text { (as } \mathrm{SO}_{4} \text { ) }\end{array}$ & $\begin{array}{c}\text { Iron, } \\
\text { filtered } \\
(\mu \mathrm{g} / \mathrm{L} \\
\text { as Fe) }\end{array}$ \\
\hline \multicolumn{11}{|c|}{ Mississippi River at Belle Chasse, 1977-20091 } \\
\hline Median & 408 & 8.2 & 7.7 & 150 & 39 & 12 & 22 & 28 & 48 & 15 \\
\hline 10th percentile & 316 & 6.1 & 7.2 & 120 & 32 & 9.3 & 13 & 17 & 34 & $<3$ \\
\hline 90th percentile & 521 & 11.7 & 7.9 & 180 & 47 & 16 & 36 & 42 & 70 & 42 \\
\hline Number of samples & 189 & 184 & 188 & 182 & 182 & 182 & 182 & 182 & 182 & 121 \\
\hline \multicolumn{11}{|c|}{ SMCLs } \\
\hline & NA & NA & $6.5-8.5$ & NA & NA & NA & NA & 250 & 250 & 300 \\
\hline
\end{tabular}

${ }^{1}$ Station number 07374525 (U.S. Geological Survey, 2012; specific data at http://nwis.waterdata.usgs.gov/la/nwis/qwdata/?site_no=07374525).

\section{Selected References}

Hem, J.D., 1985, Study and interpretation of the chemical characteristics of natural water (3d ed.): U.S. Geological Survey Water-Supply Paper 2254, 264 p., accessed February 20, 2013, at http://pubs.er.usgs.gov/publication/wsp2254.

Rollo, J.R., 1962, Ground water in Plaquemines Parish, Louisiana: U.S. Geological Survey Open-File Report, 8 p.

Rollo, J.R., 1966, Ground-water resources of the greater New Orleans area, Louisiana: Department of Conservation, Louisiana Geological Survey, and Louisiana Department of Public Works Water Resources Bulletin no. 9, 69 p.

Louisiana Department of Environmental Quality, 2008, Environmental Regulatory Code, Title 33, Part IX, Subpart 1: accessed June 9, 2009, at http:www.deq.louisiana.gov/portal/ tabid/1674/Default.aspx.

Sargent, B.P., 2011, Water use in Louisiana, 2010: Louisiana Department of Transportation and Development Water Resources Special Report no. 17, 135 p.
U.S. Environmental Protection Agency, 1992, Secondary Drinking Water Regulations - Guidance for nuisance chemicals: U.S. Environmental Protection Agency publication EPA 810/K-92-001, 4 p., accessed September 28, 2011, at http://water.epa.gov/drink/contaminants/ secondarystandards.cfm.

U.S. Environmental Protection Agency, 2012, 2012 Edition of the drinking water standards and health advisories: U.S. Environmental Protection Agency publication EPA 822-S12-001, Office of Water, 12 p., accessed August 7, 2012, at http://water.epa.gov/action/advisories/drinking/upload/ dwstandards2012.pdf.

U.S. Geological Survey, 2012, Water quality samples for Louisiana [data for USGS 07374525 Mississippi River at Belle Chasse, La.]: National Water Information System Web Interface, accessed June 2, 2009, at http://nwis.waterdata. usgs.gov/la/nwis/qwdata/?site_no $=07374525$.

Wells, F.C., 1980, Hydrology and water quality of the lower Mississippi River: Louisiana Department of Transportation and Development, Office of Public Works Water Resources Technical Report no. 21, 83 p. 
This fact sheet was published by the U.S. Geological Survey, in cooperation with the Louisiana Department of Transportation and Development (DOTD). Thanks are given to Zahir "Bo" Bolourchi, Director, Water Resources Programs, Louisiana Department of Transportation and Development, who contributed to the content and design of the fact sheet.

\section{By Lawrence B. Prakken}

\section{For additional information, contact:}

Director, USGS Louisiana Water Science Center 3535 S. Sherwood Forest Blvd., Suite 120

Baton Rouge, LA 70816

E-mail: dc_la@usgs.gov

Fax: (225) 298-5490

Telephone: (225) 298-5481

Home Page: http://la.water.usgs.gov 